INTERNATIONAL JOURNAL OF RESEARCHES IN BIOSCIENCES, AGRICULTURE AND TECHNOLOGY (c) VISHWASHANTI MULTIPURPOSE SOCIETY (Global Peace Multipurpose Socie ty) R. No. MH-659/13 (N) www.vmsindia.org

\title{
CENTRIC DIATOMS FROM KABRAYA-KHADAK DAM OF DHULE DISTRICT (M.S.)
}

\author{
M. R. Kumavat ${ }^{1}$ and S. S. Kabre ${ }^{2}$ \\ 1S. S. V. P. S's L.K.. Dr. P. R. Ghogrey Science College,Dhule. \\ ${ }^{2}$ G. D. M. Arts K.. R.. N. Commerce And M. .D. .Science College, Jamner, District Jalga on \\ mrk7869@gmail.com
}

\begin{abstract}
:
Keywords: Diversity, Freshwater, Centric-Diatoms Dam

\section{Introduction:}

Biodiversity of various groups of algae were studied in India, but very few workers (Ghandhi1958, 1959a, 1959b, 1960; Venkataraman, 1939; Sarode and Kamat1980a,1983, 1984; Bharate and Tarar,1983;Nandan, and Mahajan, 2006.) have paid attention on Diatom. The present account were carried out by selecting freshwater habitats of Kabraya-Khadak dam (71 01 N latitude ,21 42'E longitude) in Dhule District of North Maharashtra region. Diatoms are ubiquitous and form quite importance group in the aquatic ecosystem and are also important in polluted. The most Characteristic feature of the diatom cell is its ability to secrete an external skeleton of silica called the frustules. The size, shape and sculpturing of diatoms cell walls are taxonomically diagnostic.
\end{abstract}

The Diatoms are characterized by number of features, they are most easily recognized by the ir siliceous (opaline) cell walls. The size, shape and sculpturing of diatoms cell walls are taxonomically diagnostic , (Werner,1977) Diatoms are important group in aquatic ecosystem and very important ink in the food the food cycle, diatoms may contribute 20 to 25 percent World net primary production. The present paper deals with the taxonomic considerations seven taxa of freshwater centric diatoms from Kabraya-Khadak dam of Dhule distric Maharashtra.

\section{Materials and Method:}

Monthly algal samples were collected during November 2006 to October 2007. From six different sites of Kabraya - Khadak dam . (Viz. KKDS - I; KKDS - II; KKDS - IIIT KKDS IV; KKDS - V' and KKDS - VI.) he collections were preserved in 4\% formalin added with glycerin. For identification of the diatoms we re cleaned according to the Brun's me thod (Sarode and Kamat1984).The sample were treated with concentrated acids. to remove carbonates and organic material. The cleaned material was preserved in $75 \%$ alcohol. The identification of the taxa has been done with the help of standardized and other relevant and recent literature Cleve-Eruter 1951- 53, Sarode and Kamat 1984; Ghandi 1956, 1960; Hustedt, F. (1933)
SYSTEMATIC ENUMERATION:

1) Melosira granulate (Ehr.) Ralfs, Var. mazzanensis Meister

P1. I, Fig. 1

Filaments with narrow, long cells, frustles 12.2-15 $\mu \mathrm{m}$ diameter semicells 8.5$11.1 \mu \mathrm{mhig}$, end cells with spine and furrows of areoles $8-9 \mu \mathrm{m}$ se micells, spirally disposed.

This diatom was fond in brownish filamentous mass on submerged aquatic plant in dam site KKDS - I, KKDS - III , and KKDS - V.

2) Meosira distance (Ehr.) Kutz. Var. alpigena Grun.

P1. I. Fig. 2

Frustules 4-20 $\mu \mathrm{m}$.in diameter, short cylindrical, united in chains, semicells $4-8.5 \mu \mathrm{m}$. in height areoles $3-8 \mu \mathrm{m}$. in $10 \mu \mathrm{m}$.

This diatom was collected from dame site KKDS - I, KKDS - III , and KKDS - VI

3) Melosira islandica O.muel. Var. helvetica O.muell.

Frustules $8-10 \mu \mathrm{m}$ in diameter cylind rical, united in chains, semicels, 11.5-14 $\mu \mathrm{m}$ high; rows of areoles $13-14$ in $10 \mu \mathrm{m}$ strainght

This diatom was collected from dame site KKDS - I KKDS - III , , KKDS - V and KKDS - VI.

\section{4) Cyclotella meneghiniana Kutz.}

Pl. I Fig. 4.

Frustues rectunguar in gurde view. With undulate valves; valves discoid, 11-18 $\mu \mathrm{m}$. in diameter, margins strongs; central field large and finaly punctuate, striaes 8-10 in $10 \mu \mathrm{m}$. thick.

This diatom was fond on bank soil in dam site KKDS - I, KKDS - III, and KKDS - VI.

5) Cyclotella striata (Kutz.) Grun.

P1. I . Fig. 5 
Valves with strong wavy margins in the girdle view and more or less broad evenly striated border, valves discoid $14.5-25 \mu \mathrm{m}$. in diameter, central field with flexes and coarsely punctuate, striate $7-9$ in $10 \mu \mathrm{m}$.

This diatom was collected from dame site in KKDS - III , KKDS - V, and KKDS - VI

\section{6) Cyclotella operculata (Ag.)Kutz.}

PL. I. fIg. 6

Valves with thin margins in the girdle view evenly striated border, valves discoid, 6 $30 \mu \mathrm{m}$. in diameter central field with flexes staiae $13-15$ in $10 \mu \mathrm{m}$. fine.
This diatom was collected from dame site in KKDS - I, and KKDS - V .

\section{7) Cyclotella catenata Brun.}

P1.I Fig. 7.

Frustules found in chains; valves $17.4 \mu \mathrm{m}$. in diameter arched, convex surface slightly depressed in the middle; middle field radially puncatae form radial striae strong 11 12 in $10 \mu \mathrm{m}$.

This diatom was collected from dame site in KKDS - III.

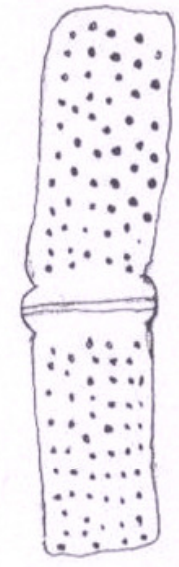

1

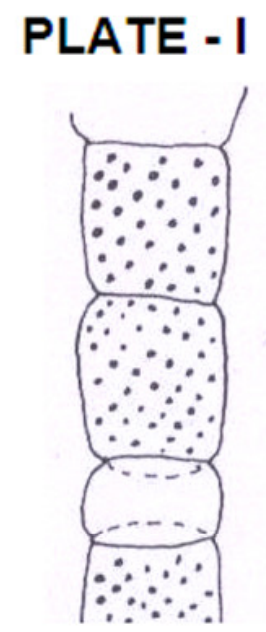

2

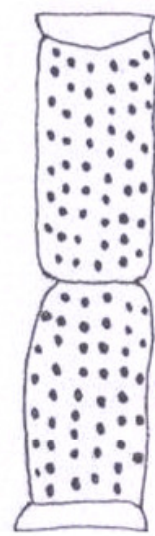

3

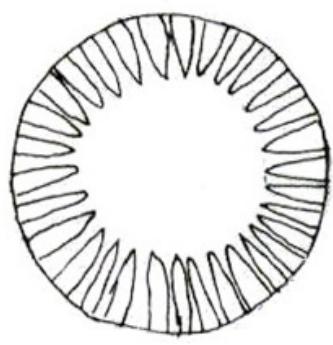

4

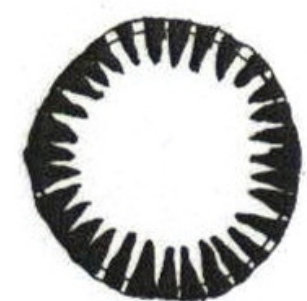

5

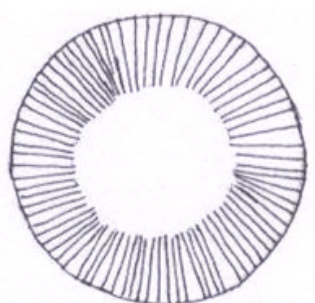

6

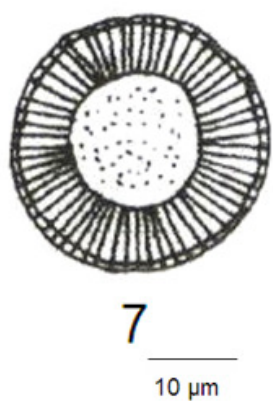

Fig. 1) Melosira granulate (Ehr.) Ralfs, Var. mazzane

2) Melosira distance (Ehr.) Kutz. Var. alpigena Grun. nsis Meister

3) Melosira islandica O.muel. Var. helvetica O.muell

4) Cyclotella meneghiniana Kutz.

5) Cyclotella striata (Kutz.) Grun.

6) Cyclotella operculata (Ag.) Kutz.

7) Cyclotella catenata Brun.

\section{Result and Discussion}

In present study only seven texa of the centric diatoms were recorded from four site of dam viz.
KKDS - I; KKDS - III ; KKDS - V' and KKDS - VI. The genus Melosira represents three species Melosira granulate (Ehr.) Ralfs, Var. mazzanensis Meister; ) Meosira distance 
(Ehr.) Kutz. Var. alpigena Grun. Melosira islandica O.muel. Var. helvetica O.muell. and the genus Cyclotellarepresented by four species viz. Cyclotella meneghiniana Kutz; Cyclotella striata (Kutz.) Grun.; Cyclotella operculata (Ag.)Kutz; Cyclotella catenata Brun All the centric diatoms were observed epiphytic and benthic on aquatic plants and rocks .

\section{Acknowledgement:}

Authors are grateful to Dr. S. N. Nandan, Principal and Head Department of Botany, S. S. V. P. S.'s L. K. Dr. P. R. Ghogrey Scie nce College, Dhule (M.S.), for providing the facilities for investigation.

\section{References:}

Bharate, V.P, and Tarar, J.I. (1983) Addition of algal flora of Maharashtra. Diatoms from Khandesh, Phykos 22:13-17.

Cleve-Euler, A (1951-1955) Die Diatomeen von schweden und Finnland - I-V.K. Sevenska Vetens Akad. Hand1.Fjurde Ser. 2: 163; 3: 1 153; 4: 1-158; 4: 1-255;5: 1-232.

Ghandi,H.P.(1958) A contribution to our knowledge of the fresh water diatomaceae of South Western India I. Fresh water diatoms of Dharwar. J. Indian bot. soc.35:194 - 209.

Ghandi,H.P.(1958) The fresh water diatom flora of Hirebhsagar dam area, Mysore State J. Indian Bot. Sco. 37: 249-263.

Ghandi,H.P.(1959a) The fresh water diatom flora from Mugad, Dharwar District, with some ecological notes. Ceylon J. Sci. (Biol.) 2: 98-116.
Ghandi,H.P.(1959b) Fresh water diatoms from sagar in Mysore State J. Indian Bot. Sco. 38: 305-331

Ghandi,H.P.(1960) On the diatom flora of some ponds around Vasna village near Ahmedabad J. Indian Bot. Sco. 39: 558-567.

Hustedt, F . (1933) Die Kiese lalgen Deutschlands usw. Rabenhorst's Kryptogamen flora. Bd. VII. (2) P 108 f.83.

Mahajan, K.D. (2006) Taxonomical study of Diatoms from North Maharashtra Ph.D. Thesis of North Mahrashtra Unive rsity, Jalgaon (M.S.)

Nandan, S.N. and Mahajan, K.D. (2006) Taxonomical study of Bacillariophyceae of Shindkheda taluka of Dhule District (M.S.) Bioinfolet, Vol.-3 (30): 154-162.

Srode,P.T. and Kamat,N.D.(1980a) The diatom flora of Nagpur, India NovaHedwigia 32:797883.

Srode,P.T. and Kamat,N.D.(1983) The diatom flora at Viderbha, India Bioliotheca Phycologia, J. Cramer (66): 259-3 19.

Srode,P.T. and Kamat,N.D.(1984) Fresh water Diatoms of Maharashtra, Saikrupa Prakasan, Aurangabad P.1-338.

Venkataraman G ( 1939) A systematic account of some south Indian diatoms Proc. Indian Acad. Sci. 10:293-368.

Warner,D. (1977) Introduction with a note on taxonomy in Biology of Diatoms Ed.D. Warner. Botanical Monographs Vol. 13 Blackwell, London: 1-17. 